\title{
The Effect of Constructivist Learning Models with Character Through Lesson Study and Critical Thinking on Learning
}

\section{Outcomes in Learning Planning}

\author{
Abdul Hasan Saragih ${ }^{1}$, R. Mursid ${ }^{2}$, Harun Sitompul ${ }^{3}$ \\ $\left\{\right.$ ahasansaragih@gmail.com ${ }^{1}$, mursid.tp@gmail.com ${ }^{2}$, prof_runsit@yahoo.co.id ${ }^{3}$ \} \\ Education Technology, Universitas Negeri Medan, Medan, North Sumatera, Indonesia ${ }^{1,2,3}$
}

\begin{abstract}
This research aims to determine: (1) the influence of constructivistic and expository learning models on lesson study towards learning outcomes in teaching planning; (2) the influence of high and low critical thinking skills on learning outcomes in teaching planning; and (3) interaction between learning models and the ability to think critically about learning outcomes in teaching planning. The research method using quasi-experimental with a $2 \times 2$ factorial design. The statistical test using descriptive statistics to present data and continued with inferential statistics using two-way ANOVA with a significant level of $\alpha=0.05$ followed by further testing. The results of research obtained showed: (1) learning outcomes in teaching planning taught using constructivist learning model with character by lesson study are higher than learning outcomes taught by expository; (2) learning outcomes in teaching planning that have high critical thinking skills are higher than those with low critical thinking skills; and (3) there's an interaction between the learning model and the ability to think critically about the learning outcomes of teaching planning.
\end{abstract}

Keywords: learning model, character based, constructive, lesson study, critical thinking, learning planning.

\section{Introduction}

Lesson study was a model for educating professional development through collaborative and ongoing learning assessment based on the principles of collegiality by a group of teachers to build a learning community. Lesson Study was not a strategy or method of learning, but lesson study activities can apply various strategies and learning methods that can be adapted to the situations and conditions and problems faced by teachers in each learning process (Rusman, 2011).

During this time, the learning process in the mechanical engineering study program in the Teaching Planning course was seen from the learning completeness and student learning outcomes, there was no indication of a significant problem as in the courses in the education family. However, in the learning process that takes place in the classroom to date, it was still centered on lecturers or often called teacher centered or known as traditional approaches 
(Utami, et al: 2011). In that learning, lecturers as individuals who are more active in teaching and students act as objects that receive passive knowledge. Although several methods have been tried to be applied like the discussion method, but students still have not responded well. They are still passive in expressing their opinions, discussions are dominated by lecturers. If this was left unchecked, it was feared, students will bring their learning experience when they go to college to the field, namely their classes later when they become teachers.

Planning learning was the most important thing for teachers in carrying out their duties. Learning planning was a projection of something that will be done by the teacher in the teaching and learning process. Learning will be optimal if the teacher first prepares learning planning. Learning planning needs to be done by the teacher to coordinate the learning components. Character-based learning planning means preparing learning plans that prioritize aspects of attitude, behavior, and character that will be internalized into students.

Constructivism was born from the ideas of Piaget and Vigotsky. Both emphasize that cognitive change only occurs if conceptions that have been previously understood are processed through a process of disequilibrium in an effort to understand new information (Nur, 2000). Constructivism considers that knowledge was cognitive construction through one's activities. Constructivism emphasizes that humans construct objects and the relationships they feel to expand their conceptions that are appropriate to the environment. Brown quoted Duffy (1992: 4) arguing that constructivists emphasize "situating" cognitive experiences in authentic activities.

To overcome the problems above, in this study active actions were carried out that applied the learning approach to constructivism. In directing lecture material and giving examples of quality learning and tasks that must be done by students a simulation was done, so that students can really see clearly what kind of learning will be trained in the student. So students will be truly trained to make contextual learning tools and implement them in front of the class so as to make learning interesting.

Lesson study was a model for educating professional development through collaborative and ongoing learning assessment based on the principles of collegiality and mutual learning to build a learning community (Hendayana, 2007). The lesson study coaching model can be used as a teaching guidance model for lecturers towards students (Rustono, 2008). One effort to improve the quality and professionalism of teachers in facilitating the learning process. Teaching Planning courses are deliberately chosen because the content of this course was an effort to provide skills to prospective teachers to be able to design learning. Of the various learning learning planning courses, how are prospective teacher students able to design various components that support the implementation of learning so as to produce references that are in line with the willingness of stakeholders and the government through its curriculum.

Lesson study was carried out in three stages, namely: planning, implementation and reflection stages. The planning phase aims to design learning that can teach students how to actively participate in learning activities. The implementation phasing the implementation stage of the learning design that has been prepared previously. During the learning process the observer focuses attention on student activities, namely the interaction of fellow students, students with lecturers, students with teaching materials and student interaction with the environment.

After completing the learning process, a discussion between model lecturers and observers was immediately carried out. At first the model lecturer conveyed impressions during the learning process, then continued by observers. Observers must convey the facts of their findings in class honestly and wisely in order to improve the learning process. Model 
lecturers must be able to receive input from observers to improve learning in the next stage. In principle, all the people involved in the lesson study activities must obtain lesson lessons. Thus lesson study activities can be used to build a learning community (Rusman. 2011).

Character can be interpreted as a basic value that builds a personal person, formed either because of the influence of heredity or environmental influences, which distinguishes it from others, and was manifested in attitudes and behavior in everyday life. In simple terms, character education was defined as anything positive what the lecturer does and influences the character of the students he teaches. Character education was only part of good learning and fundamental part of good education (Samani and Hariyanto.2011).

According to Ennis (1996), critical thinking reasoned and reflective thinking by emphasizing decision making about what to believe or do. Indicators of critical thinking derived from critical activities according to Ennis (1996) are five, namely (1) able to formulate the main issues; (2) able to reveal the facts needed to solve a problem; (3) able to choose logical, relevant and accurate arguments; (4) able to detect biases based on different points of view; and (5) able to determine the consequences of a statement taken as a decision.

Iakovos (2011) explains that critical thinking and creative thinking have an important role in education and the main goal in learning where there are four important components for building these abilities, namely (1) explaining and clarifying; (2) asking the right questions to clarify or challenge; (3) consider the credibility of the source; (4) problem solving and drawing conclusions.

The problems that will be examined in this study, can be formulated as follows: (1) Are there differences in teaching planning learning outcomes taught by constructivistic and expository learning models in lesson study; (2) Are there differences in learning outcomes of teaching planning that have high critical thinking skills and who have low critical thinking skills; and (3) Are there any interactions between the learning model and the ability to think critically about the learning outcomes of the pursuit planning?

\section{Methods}

This research was carried out Mechanical Engineering education study program, Odd semester 2017/2018 academic year. The research population were students of mechanical engineering education who took teaching planning subjects, which consisted of 4 classes, and each class consisted of 22 students, which means the population of this study consisted of 88 students. Whereas the sample of this study was set in 4 classes with the technique (Cluster Random Sampling). The design of the study was a $2 \times 2$ factorial experiment. The learning model was divided into two, namely the elaboration learning model and the direct learning model. Critical thinking skills are also divided into two, namely high critical thinking skills and low critical thinking skills.

Data collection techniques used are test techniques. The test used for data collection, which was a test to measure the learning outcomes of teaching planning through lesson study that was prepared based on learning outcomes according to the IQF. The second testing to measure critical thinking skills. Validity testing done using biserial correlation. While the valiadility test was carried out using K.R-20

Data analysis techniques are carried out using descriptive and inferential statistics. Descriptive techniques are to describe data (mean, median, and standard deviation). While inferential 
techniques are to test hypotheses. The inferential technique used to test the hypothesis of this research was 2-way variance analysis (ANAVA) technique and continued with further testing.

\section{Results}

Description of statistical data learning outcomes planning planning based on variations in learning models are as follows.

Description of learning outcome data based on variations in learning models. The learning outcomes of student teaching planning in the experimental group taught using constructivist learning models are better than the learning outcomes of the control group students who are taught using the expository learning model in lesson study.

Description of learning outcome data based on variations in critical thinking skills. Learning outcomes of teaching planning for students who have high critical thinking skills are better than the learning outcomes of students who have low critical thinking skills.

Based on the calculation that the value of $0.227>0.05$, the standard residual was normal. Based on the calculation results show that the significance value was 0.217 . And because the significance value $0.217>0.05$, it can be concluded that the variance in the learning outcome planning variable was homogeneous. So it was assumed that homogeneity in the two way ANOVA test was fulfilled.

Table 1: Descriptive Analysis Calculation Results

\begin{tabular}{|c|c|c|c|c|}
\hline $\begin{array}{c}\text { Learning } \\
\text { model }\end{array}$ & Critical Thinking Ability & \multicolumn{3}{|c|}{$\begin{array}{c}\text { Std. } \\
\text { Deviati on }\end{array}$} \\
\hline $\begin{array}{l}\text { Construc } \\
\text { tivistic }\end{array}$ & $\begin{array}{l}\text { High Critical } \\
\text { Thinking Ability }\end{array}$ & 84.23 & 3.449 & 22 \\
\hline Model & $\begin{array}{l}\text { Low Critical } \\
\text { Thinking Ability }\end{array}$ & 71.82 & 3.473 & 22 \\
\hline & Total & 78.02 & 7.148 & 44 \\
\hline $\begin{array}{l}\text { Exposito ry } \\
\text { Model }\end{array}$ & $\begin{array}{l}\text { High Critical } \\
\text { Thinking Ability }\end{array}$ & 80.55 & 2.773 & 22 \\
\hline & $\begin{array}{l}\text { Low Critical } \\
\text { Thinking Ability }\end{array}$ & 67.23 & 3.085 & 22 \\
\hline & Total & 73.89 & 7.333 & 44 \\
\hline Total & $\begin{array}{l}\text { High Critical } \\
\text { Thinking Ability }\end{array}$ & 82.39 & 3.610 & 44 \\
\hline & $\begin{array}{l}\text { Low Critical } \\
\text { Thinking Ability }\end{array}$ & 69.52 & 3.991 & 44 \\
\hline & Total & 75.95 & 7.494 & 88 \\
\hline
\end{tabular}


Table 2: Results of Average Score of Learning Outcomes of Teaching Planning in Constructivistic and Expository Learning Models

\begin{tabular}{|c|c|c|c|c|}
\hline \multirow{2}{*}{$\begin{array}{l}\text { Constructivist Learning and } \\
\text { Exploration Models }\end{array}$} & \multirow[b]{2}{*}{ Mean } & \multirow[b]{2}{*}{$\begin{array}{l}\text { Std. } \\
\text { Error }\end{array}$} & \multicolumn{2}{|c|}{$\begin{array}{c}95 \% \\
\text { Confidence } \\
\text { Interval }\end{array}$} \\
\hline & & & $\begin{array}{l}\text { Lower } \\
\text { Bound }\end{array}$ & $\begin{array}{l}\text { Upper } \\
\text { Bound }\end{array}$ \\
\hline $\begin{array}{l}\text { Constructivistic } \\
\text { Model }\end{array}$ & 78.023 & 0.484 & 77.061 & 78.984 \\
\hline Exploration Model & 73.886 & 0.484 & 72.925 & 74.848 \\
\hline
\end{tabular}

Based on the results of calculations in Table 4 shows that there was a difference in the average value of learning outcomes of student planning teaching groups based on the application of constructivist learning models in the lesson study. The average learning outcome group teaching planning of students taught by constructivistic learning model was 78.023 higher than the average learning outcome group teaching planning of students taught by exploration learning model was73.886.

Table 3: Difference in Average Value of Learning Outcomes of Teaching Planning on Critical Thinking Ability

\begin{tabular}{lllll}
\hline & & & \multicolumn{2}{c}{$95 \%$ Confidence } \\
Interval \\
Critical \\
$\begin{array}{c}\text { Thinking } \\
\text { Ability }\end{array}$ & Mean & Std. Error & $\begin{array}{l}\text { Lower } \\
\text { Bound }\end{array}$ & $\begin{array}{c}\text { Upper } \\
\text { Bound }\end{array}$ \\
\hline $\begin{array}{c}\text { High Critical } \\
\text { Thinking } \\
\text { Ability }\end{array}$ & 82.386 & 0.484 & 81.425 & 83.348 \\
$\begin{array}{c}\text { Low Critical } \\
\text { Thinking }\end{array}$ & 69.523 & 0.484 & 68.561 & 70.484 \\
Ability & & & & \\
\hline
\end{tabular}

Based on the results of calculations in table 5 shows that there was a difference in the average value of learning outcomes of the planning of student groups based on the ability to think critically. The average learning outcomes group planning machine teaching students with high critical thinking ability was 82.386 higher than the average learning outcome group teaching planning students with low critical thinking ability 69.523 .

Calculation of inferential statistical analysis uses (ANOVA) two lines 2 x 2. Below was a summary table of the results of the two-track ANOVA test in table 6 below. 
Table 4: Calculation Results of ANOVA Factorial 2x2

\begin{tabular}{cccccc}
\hline Source & $\begin{array}{c}\text { TypeIII Sum } \\
\text { of Squares }\end{array}$ & df & $\begin{array}{c}\text { Mean } \\
\text { Square }\end{array}$ & F & Sig. \\
\hline $\begin{array}{l}\text { Corrected } \\
\text { Model }\end{array}$ & $4021.364 \mathrm{a}$ & 3 & 1340.45 & $\begin{array}{c}130 . \\
25\end{array}$ & 0.00 \\
& & & & 493 & \\
Intercept & 507680.18 & 1 & $\begin{array}{c}507680 . \\
18\end{array}$ & $\begin{array}{c}31.8 \\
4\end{array}$ & 0.00 \\
& & & & 36.5 & 0.00 \\
Model & 376.41 & 1 & 376.41 & 7 & \\
& & & & 353. & 0.00 \\
Think & 3640.41 & 1 & 3640.41 & 74 & 0.51 \\
$\begin{array}{c}\text { Model } * \\
\text { Think }\end{array}$ & 4.54 & 1 & 4.54 & 0.44 & \\
$\begin{array}{c}\text { Error } \\
\text { Total }\end{array}$ & 864.455 & 84 & 10.291 & & \\
Corrected & 512566.000 & 88 & & & \\
Total & 4885.818 & 87 & & & \\
\hline
\end{tabular}

a. R Squared $=.823$ (Adjusted R Squared $=.817$ )

Based on the ANOVA calculation results in table 6, it can be used to answer the research hypothesis proposed:

Hypothesis 1. The results of the analysis of two- way variants of the data of learning outcomes of teaching planning are reviewed based on the learning model obtained the value of F count value of 36.576 with a significance of 0.000 ( $\mathrm{Sig}<0.05$ ). Because Fcount has a significance of less than 0.05 ( $\mathrm{Sig}=0.000<0.05$ ), then $\mathrm{H} 0$ was rejected and Ha was accepted. Thus it can be concluded that there are differences in learning outcomes between classes that use constructivist learning models with classes that use an exploratory learning model on lesson study.

Hypothesis 2. The results of the analysis of two- way variants of the data of learning outcomes of critical thinking ability and low critical thinking ability obtained Fcount value of 353.743 with a significance of 0.000 ( $\mathrm{sig}<0.05$ ). Because Fcount has a significance of less than 0.05 ( $\mathrm{sig}=0.000<0.050$ ), then $\mathrm{H} 0$ was rejected and Ha was accepted. Thus it can be concluded that there are differences in learning outcomes of teaching planning students who have high critical thinking skills with students who have low critical thinking skills.

Hypothesis 3. The results of the analysis of two- way variants of the data of teaching planning learning outcomes are reviewed based on the interaction between constructivist learning models and critical thinking ability obtained Fcount value of 0.442 with a significance of 0.508 ( $\mathrm{sig}>0.05$ ). Because Fcount has a significance of more than 0.05 ( $\mathrm{sig}=$ $0.254>0.050$ ), then $\mathrm{H} 0$ was accepted and $\mathrm{Ha}$ was rejected. Thus it can be concluded that there was no interaction between the use of learning models (elaboration and direct in the context of text content) with the ability to think critically about the learning outcomes of teaching planning on the lesson study. 


\section{Discussions}

Are the learning outcomes of the teaching planning of students taught using constructivistic learning models higher than those taught using the expository learning model in lesson study.

The first research hypothesis about the difference in the influence of constructivistic and expository learning models in the lesson study of students was accepted. This shows that the two learning models used in the study will influence student learning outcomes. From the mean value of the students' teaching planning learning outcomes can also be seen the difference between students taught using constructivist learning models and students taught using the expository learning model in lesson study.

The results showed that the use of character and constructivist teaching planning learning models through lesson study allows students to improve their ability to think carefully about learning goals, subject matter, and the field of study not only to pay attention to learning for one meeting or one subject, but how to teach one the subject matter unit and even the field of study, and also pay attention to the development of students in the longterm.

The use of constructivist learning models in character teaching planning through lesson study allows students to also design collaborative learning

and provide opportunities for students to design learning. According to Lewis (2002), as an illustration that the average teacher in Japan observed about 10 lessons studied each year. Teachers in Japan perceive that collaborative activity was very beneficial. Collaborative activity can provide opportunities for teachers to think about their own learning after considering it with the experience of other teachers. Through lesson study the teacher can learn from each other through shared knowledge activities.

Through lesson studying coaching model for students in collaborative and ongoing learning assessment, based on the principles of collegiality that helps each other in learning to build a learning community. The principle of collegiality and mutual learning are applied in collaborating when implementing lesson study activities. In other words, students of lesson study activities carried out in teaching planning learning should not feel superior (feel smartest) or inferior (feel inferior) but all must have the intention to learn from each other. Students who already understand or have more knowledge must be willing to share with students who do not understand, otherwise students who do not understand must want to ask students who already understand. The study activities for learning through lesson studies like this will improve the learning community.

The learning process in teaching planning conducted by students in practice with constructivistic and expository based on the characters in the application of lesson study was superior which carried out through constructivist learning models. By constructing thinking skills and developing pursuit plans tailored to learning problems and learning conditions requires a solution to make learning activities run well and constructively. In line with what Lewis (2002) explained, that the learning process must be well designed to make teachers professional and innovative. By implementing lesson study the teachers can (1) determine the competencies that students need to have, plan and implement effective lessons; (2) reviewing and improving lessons that are beneficial for students; (3) deepening knowledge of subjects presented by teachers; (4) determine the competency standards that will be achieved by students; (5) collaborative lesson planning; (6) examine students' learning and behaviour carefully; (7) develop reliable learning knowledge; and (8) reflecting on the teaching carried out based on the views of students and colleagues. 
Through Lesson Study, the students involved in the teacher realized the importance of lesson study in improving teacher professionalism because it can improve pedagogic competence by looking at the various methods implemented during learning, academic competency by collaborative learning plans, social competence by giving each other, accept the results of reflection, and share the concept of material, and professional competence by always having a desire for lifelong learning. Lesson studying one of the efforts to improve teacher professionalism to improve the quality of learning so that its implementation needs to be continuously carried out and developed in various schools. (Chotimah, 2015). Supported by the results of research by Rahayu, Mulyani, and Miswadi (2012), showed that the results showed that using the Problem Base learning model through lesson study could help teachers to develop a set of learning tools and provide better learning. The research shows that through the lesson study activities the aim was the same to increase teacher professionalism through improving teaching methods and increasing knowledge (Cerbin \& Kopp, 2006). Observation of student learning activities, aims to find out the teaching method or method of teaching that can be done or not, so that from observation of students can be used to correct and improve the learning method used in teaching planning courses.

Are the learning outcomes of teaching planning for students who have higher thinking skills higher than students who have low thinking skills.

The second research hypothesis about the difference between high critical thinking abilities and low critical thinking skills in planning student learning was accepted. This shows that both critical thinking skills used in research will influence student learning outcomes. From the mean value of learning outcomes of student teaching planning can also be seen the difference between students who are taught with high critical thinking skills and students who are taught using low critical thinking skills in lesson study.

Students who have high critical thinking skills are more creative and active in learning. With high critical thinking skills students are more eager to learn and like challenges, and they will be able to learn something well, so that through problem-based learning strategies students who have high critical thinking skills tend to be better at solving problems and through solving these problems students can develop critical thinking skills to be even better.

This consistent with the opinion of Sardiman (2010:75) that in learning activities critical thinking skills can be said to be the overall power in the student which leads to learning activities, which ensures the continuity of learning activities and which gives direction to learning activities, so that desired by the subject of learning can be achieved.

The results show that students who have critical thinking dispositions are sensitive to critical thinking moments, feel compelled to think critically, and have basic skills for critical thinking. Although included in the element of ability in the disposition concept, Perkins (Suriadi, 2006) states that in reality the use of critical thinking dispositions was only an element of tendency and sensitivity. While the element of ability was only a clue that people who have a critical thinking disposition must also have the ability (cognitive skills). Therefore, good critical thinkers always try to equip themselves with the disposition of critical thinking, not just cognitive skills. Critical thinking in every discipline varies. Poedjiadi (1999) states that in order to be able to carry out critical thinking in certain disciplines, must first master the terminology, concepts, and methodologies of the science.

To make students think critically, it can be through observation of a constructivist learning model with character in an effort to make critical thinking. By observing a model we can help students imagine, explain and carry out the behavior that will be done. People who are considered models in critical thinking show the nature of being able to explain the reason for the action clearly so that it can be understood by those who observe it. Be responsible and 
acknowledge the shortcomings, or the success that was done. This can be conditioned in the classroom in the presentation of the results of the completion of the task by providing an opportunity for students to provide opinions and critics according to what they think.

To be a critical thinker, students need to familiarize themselves with open mindedness, using logical evidence and correct logic to be able to understand in depth the events so that they can act and draw conclusions appropriately (Elaine, 2011). Through the application of constructivist learning models through lesson study can be seen increasing critical thinking skills by: reading critically, improving analytical skills, developing observing/observing skills, increasing curiosity, ability to ask questions and reflection, metacognition, observing "models" in critical thinking, "rich" discussion, critical thinking evaluation (Zaleha IH, 2004:95).

\section{Conclusions}

The conclusion of this study shows that: (1) The average learning outcomes of the teaching planning of students taught using constructivist learning models are superior to using expository learning models in lesson study; (2) the average learning outcomes of students' teaching planning with high critical thinking skills are superior to those with low critical thinking abilities; (3) there was a difference in the results of students learning mechanical drawing between classes using constructivist learning models with those using expository learning models in lesson study, (4) there are differences in learning outcomes of students' teaching planning on those who have high critical thinking skills with students who have the ability low critical thinking. (5) there was no interaction between the use of constructivist and expository learning models in lesson study with the ability to think critically about the learning outcomes of teaching planning. 


\section{References}

[1] Cerbin, W \& Kopp, B.: Lesson Study a Model For Building Pedagogical Knowledge and Improving Teaching. International journal of teaching and learning in higher education, 18 (3): pp. 250-257.(2006)

[2] Chotimah, C., 2015. Peningkatan Profesionalisme Guru Melalui Lesson Study Untuk Upaya Meningkatkan Kualitas Pembelajaran. Prosiding Seminar Nasional Pendidikan Biologi FKIP Universitas Muhammadiyah Malang, 21 Maret 2015.

[3] Elaine B. J.: CTL Menjadikan Kegiatan Belajar Mengajar Mengasyikkan dan Bermakna, Kaifa. Bandung.(2011)

[4] Ennis, R. H.: Critical Thinking. Prentice-Hall Inc.New Jersey (1996)

[5] Iakovos, T.: Critical and Creative Thinking in the English Language Classroom. International Journal of Humanities and Social Science.Vol 1, No 8(2011)

[6] Lewis, C.C., 2002. Lesson study: A Handbook of Teacher- Led Instructional Change. Research for Better Schools, Inc. Philadelphia,PA(2002) 